\title{
IMPROVING PROFESSIONAL COMPETENCE AND KNOWLEDGE SHARING BASED ON ORGANIZATIONAL CITIZENSHIP BEHAVIOR TOWARD HUMAN RESOURCES PERFORMANCE
}

\author{
Agustina Maulidatur Rika ${ }^{1^{*}}$, Tatiek Nurhayati ${ }^{2 *}$
}

\begin{tabular}{l}
\hline * Affiliation: \\
${ }^{1}$ Director of Fath Company \\
Rikafachrureza20@gmail.com
\end{tabular}

\section{Abstract :}

This study aims to describe and analyze the effect of organizational citizenship behavior on HR performance with professional commitment and knowledge sharing as an intervening variable. The population used is the total number of employees of local water company (PDAM) Semarang total of them are 569 people, with a total sample of 85 people. The sampling technique is Proportional Random Sampling. The analysis tool is Partial Least Square. Another test result shows that OCB has a positive effect on professional competence. The test proves that OCB and professional competencies have a positive effect on knowledge sharing. Organizational citizenship behavior, professional competence and knowledge sharing have a positive effect on HR performance. The test results show that professional competence is able to be an intervening variable between OCB and knowledge sharing, while professional competence is not able to be an intervening variable between OCB and HR performance. Knowladge sharing is able to be an intervening variable between $\mathrm{OCB}$ and $\mathrm{HR}$ performance and knowledge sharing can also be an intervening variable between professional competence and HR performance.

Keywords: Organizational citizenship behavior, professional commitment and knowledge sharing and performance of Human Resources

\section{INTRODUCTION}

The success of the company is strongly influenced by the individual performance of its employees. To achieve optimal performance requires high professional competency of employees and the ability to share knowledge. The high level of employees's professional competence will certainly affect the completion of workjobs that are charged as a form of responsibility held in improving optimal performance.

Knowledge Sharing is the interaction and communication between individuals and business units (Reed, Srinivasan and Doty 2009 in Sumarlin, et al, 2013). To support effectiveness of knowledge sharing, companies must build communication (social and technical) that is good and allow individuals or groups to interact well. Sharing knowledge will increase the understanding of another company members so the members will support each other and will find the best work processes then at the end it will improve the company performance. 
It based Matzler et al. (2008) statement that knowledge sharing will contribute to help improve organizational performance. For this reason, so employee performance can be maximized, it requires the behavior of employees who not only do their main tasks, but want to do the task extras like cooperating, please help, give advice, participate actively (Organizational Citizenship Behavior).

Organizational citizenship behavior (OCB) is a unique aspect of individual activity in work, due to employees who behave OCB do not only do their main tasks but also want to do extra tasks. Organizational citizenship behavior contributes to improving organizational effectiveness, because employees who want to work extra are certainly formed because of the high professional competence they have. Borman and Montowidlo (1993) in Novliadi (2007) explained that OCB can improve competence because employee behavior can be seen from social interactions with other members of the organization to be well done, reduce disputes, and improve efficiency Organizational effectiveness will increase when employees work beyond the call of duty and even help fellow workers in order to achieve organizational goals. It based on the statement of Lovell (1999) in Lestari, et al. (2015) that Organizational Citizenship Behavior is a behavior that extends and exceeds what behavior has been required by the organization to improve employee performance. Organizations will benefit from the encouragement of employees to get involved in OCB, because it has been proven to increase productivity, the ability to share knowledge, and reduce costs and turnover and absenteeism (Muhdar, 2015).

The Regional Water Company (PDAM) is Semarang Government-Owned Enterprise that provides community services through the provision of drinking water. PDAM Semarang has a vision that is "To be the best and the best choice of drinking water provider in Indonesia". To realize this vision, the role of employees is takes dominant element in maximize the performance. In improving employee performance, the management of the company has made various efforts including rotating employees, conducting education and training for them. It has been done so the result performance is more optimal. The phenomenon in the reality shows that the efforts made by the management of the PDAM have not been able to bring about better changes in improving the performance of PDAM employees.

The research on the human resource performance has been carried out by several previous researchers, such as the results of the Khazaei, et. al. (2011); Suzana (2017); Rastgar, et.al. (2012); Harwiki (2013); Maharani, et.al. (2013), Putri and Utami (2017) show that organizational citizenship behavior has a positive effect on HR performance. While Sudiro's (2014) research, Ramadhani (2013) and Sanjaya and Setiawan (2017) showed that organizational citizenship behavior does not affect employee performance.

The research conducted by Hakim (2015) and Haryaka (2016) shows that professional competence influences learning performance. Likewise, the research of Subari and Riady (2015) and Ibrohim (2016) also shows the same results that individual competence has a positive effect on employee performance. In contrast to the research conducted by Rahayu (2011) that professional competence does not affect teacher performance.

Another research conducted by Maharani and Susanti (2013) shows that knowledge sharing influences business performance. However, the results of research conducted by Fitriyana (2012) occur otherwise that knowledge sharing does not affect business performance. 
So, in the case with Zaied's (2012) study that knowledge sharing also does not affect employee performance.

Based on these problems, it can be formulated, how so that HR performance can be increased through organizational citizenship behavior, professional competence, knowledge sharing. With these problems, the research question raised in this study is how the influence of organizational citizenship behavior on HR performance with professional commitment and knowledge sharing as intervening variables?

\section{LITERATURE REVIEW Human Resources (HR) Performance}

Simamora (2013) suggests that performance as a level at which employees reach job requirements. Performance is a record of outcomes that are generated from the function of a particular job or activity during a certain period of time. Furthermore Dessler (2009) defines performance, namely the comparison between the results of work that is real and the standard of work specified.

HR performance is an action taken by employees in carrying out work given by the company (Handoko, 2012). Every company always expects its employees to has achievements, because having employees who excel will provide optimal contributions to the company. In addition, by having employees who excel in the company can improve the performance of their company. In other word, the continuity of a company is determined by the performance of its employees.

Miner (Widjajanti and Widodo, 2014) explained that performance components can be determined by three major groups, namely: (1) related to the characteristics of the quality of work of employees; (2) relating to the quantity of work of employees; and (3) relating to the ability to cooperate with other employees. While Mathis and Jackson (2006) mention, there are several elements in measuring performance, including can be seen from the quantity of results achieved, quality of results, timeliness of results, presence and ability to work together.

While according to Riduwan (2009) that performance indicators can be assessed from the ability to have the initiative to find the best step, mastering Job Description, results achieved, level of cooperation, accuracy, level of suitability of duty with the orders, level of quality of work results, level of completion and the level of quantity of work.

\section{Organizational Citizenship Behavior}

According to Organ (2000) defines OCB as a discretionary individual behavior, which does not directly and explicitly get an award from a formal reward system, and which as a whole encourages the effectiveness of organizational functions. It is free and voluntary, because the behavior is not required by the requirements of the role or job description, which are clearly required based on a contract with the organization but as a personal choice.

While acording to Robbins (2012) Organizational Citizenship Behavior (OCB) is a choice behavior that is not part of an employee's formal work obligations, but supports the functioning of the organization effectively. Resckhe (1997) defines OCB as the contribution of individuals in exceeding the demands of roles in the workplace. This OCB involves 
several behaviors including helping others, volunteering for extra tasks, obeying the rules and procedures in the workplace.

Organ et al. (2006) say that people who carry out organizational citizenship behavior are known as "good soldiers". There are five dimensions of OCB according to Organ et al. (2006) are Altruism (Concerning the interests of others), Conscientiousness, Sportmanship, Courtessy, Civic Virtue (Maximum work)

\section{Proffesional Competence}

Competence is a characteristic that stands out for someone and looks for ways to behave and think in all situations and takes place over a long period of time (Spencer and Spencer, 2000). Thus competence refers to a person's performance in a job that can be seen from thoughts, attitudes and behavior.

According to Sedarmayanti (2010) that professionalism is a pillar that will place the bureaucracy as an effective machine for the government and as a parameter of the apparatus'

ability to work well. The measure of professionalism is competence, effectiveness and efficiency as well as being responsible. Professional comes from the word profession, which means that the work that implements it requires certain requirements. Thus a profession presents services based on science that are only understood by certain people who are systematically formulated and applied to meet the needs of others. Siagian (2011) states that what is meant by professionalism is reliability in carrying out tasks so that it is carried out with high quality, right time, carefully and with procedures that are easily understood and followed by customers. According to Raharjo and Sutomo (2016) explained that to measure professional competence can be done by mastering the material, mastering competency standards, developing professionalism on an ongoing basis, utilizing information technology

\section{Knowledge Sharing}

Hoof and Weenen (2004) define knowledge sharing as the activity of individuals exchanging personal intellectual capital. Knowledge sharing is basically an organizing principle that lays the foundation for capturing the potential of knowledge possessed in the organization. To make the most of organizational resources and increase knowledge sharing it is important to recognize that managing technology and people in order to provide a useful environment for sharing knowledge.

According to Hoof and Weenen in Maharani and Susanty (2015) explained that knowledge sharing can be measured in 2 dimensions, namely knowledge donating and knowledge collecting. Knowledge donating is an individual or group behavior to communicate the intellectual knowledge / model that is owned by others. The purpose of knowledge donation is to see how individual knowledge changes to the knowledge of the organization / group from time to time so that later the knowledge supply in the company will increase and increase. While knowledge collecting is the behavior of individuals / groups to consult with each other in order to gain knowledge of intellectual capital that is owned and communicated by others. 
According to Shannak (2009), the knowledge sharing cn be measured by:

1. Knowledge Sharingbehavior which includes join in routines discussions, exchanging experiences to solve solutions and save time, and activities

2. Knowledge Sharingisthrough participatory participation in meetings, such as workshops, seminars, or other activities

\section{HYPOTESIS DEVELOPMENT}

\section{The Effecct of $O C B$ Towards Professional Competence}

Organizational Citizenship Behavior (OCB) Organizational Citizenship Behavior (OCB) in an organization actually leads to the behavior of helping coworkers, never complaining about the work, doing their work based on what is determined, participating and tolerating the progress of the organization as a form of high employee attitudes towards the professionalism of their abilities. This is in line with what Borman and Montowidlo (1993) in Novliadi (2007) stated that Organizational Citizenship Behavior can improve competency because employee behavior can be seen from social interactions among members of the organization to be smooth, reduce disputes, and increase efficiency

OCB is a unique aspect of individual activities in work, because employees who behave OCB do not only do their main tasks but also want to do extra tasks such as willing to cooperate, please help, give advice, participate actively, provide extra services to service users, and want to use their working time effectively. This is done because employees have competence so that they bring up their professionalism as employees of their abilities.

The results of this study are similiar with the research conducted by Agus Triyanto (2008), who found that OCB has an effect on professional competence. By applying OCB, the professional competence of employees would increase. This is also supported by Lestari's research et al. (2015) if OCB has a positive influence on professional competence.

H1: OCB has a positive effect on professional competence

\section{The Effect ofOCBToward Knowledge Sharing}

Organizational citizenship behavior (OCB) is a unique aspect of individual activity in work, because employees who behave OCB do not only do their main duty but also want to do extra duty such as willing to cooperate, please help, give advice, participate actively, provide services extra for service users, and want to use their working time effectively. Thus, the higher OCB, the employee will strive to be more concerned with others, listen to heart, sportsmanship, respect and responsibility to knowledge as a form of attitude towards his abilities. According to Garay, (2006) states that the high level of employees to share knowledge is due to the encouragement that arises to behave OCB, ie behavior that exceeds what has been standardized by the company. Lovell (1999) argues that OCB is a behavior that extends and exceeds what is required by the organization to share knowledge

Research conducted by Hamzah and Djaya (2012) shows that increasing OCB affects knowledge sharing. These results are consistent with the results of other studies such as Atak 
\& Ramazan (2010) and Ellinger et al (2013), which confirms OCB has a positive influence on knowledge sharing, so the hypothesis is formulated:

$\mathrm{H}_{2}$ : OCB has a positive effect on knowledge sharing

\section{The Effect of Proffesional Competence towards Knowledge Sharing}

The employees who have high professional ability in their fields will try to share knowledge with other employees. If they face some obstacles related to automation, if employees who have high abilities or skills are not available because external duty will certainly be difficult, so employees need to share knowledge they can understand the obstacles they are faced. Thus, the higher of the professional competence possessed by the employee, the more influential the employee will be in carrying out the work assigned to him effectively, efficiently and responsibly so that he will encourage employees to share knowledge because there is an encouragement that arises in him. This is in accordance with the statement of Davenport \& Prusak (1998) that one's professional competence arises because there is an incentive in him to share knowledge.

The problem of sharing knowledge in an organization is currently an important issue in both the business and non-business fields, because all human activities are actually organizational activities. There are no activities that will run smoothly, if there is no good organization, none of benefits can be obtained, if an organization does not run well. Every organization has members who have competencies or skills based on their knowledge, will encourage sharing knowledge so there are no obstacles. The results of Rodin, et al (2017) and Haryaka (2016) showed that professional competence influences knowledge sharing. Based on the above theory and supported by previous research, the hypothesis can be formulated as follows:

$\mathrm{H}_{3} \quad$ Professional competence has a positive effect on knowledge sharing

\section{The Effect of $O C B$ towards Human Resourcces Performance}

Organizational citizenship behavior (OCB) is a unique aspect of individual activity in work, because employees who behave OCB do not only do their main duty but also want to do extra duty such as willing to cooperate, please help, give advice, participate actively, provide services extra for service users, and want to use their working time effectively. According to Garay, (2006) High performance of human resources (employees) will encourage the emergence of organizational citizenship behavior (OCB), namely behavior that exceeds what has been standardized by the company. Lovell (1999) argues that OCB is a behavior that extends and exceeds what behavior has been required by the organization to improve employee performance.

The results of several studies examined empirically include Khazaei et. al. (2011); Sugiyanto and Sutanto, (2010); Rastgar, et.al. (2012); Harwiki (2013); Maharani, et.al. 2013. Khazaei, et. al. (2011) found a significant positive relationship between OCB and employee performance.

Sugiyanto and Sutanto, (2010), OCB and employee performance are positively and significantly related because OCB is seen as one of the critical things for task success which is highly correlated with performance, believed because OCB is a social engine lubricant that has 
more role than the formal task carried out by each individual employee. Rastgar, et.al. (2012), also found a positive and significant relationship between OCB and employee performance. Harwiki (2013) found that OCB has a positive impact on employee performance. High OCB can cause higher employee performance.

$\mathrm{H}_{4}$ : OCB has a positive effect on HR performance

\section{The Effect of Professional Competence towards Human Resources Performance}

Professional competence is a set of someone'a abilities to carry out thye duty so that they are carried out with high quality, the right time, and carefully. Ability show the potential of people to carry out work, maybe that ability is implemented or maybe not. The work ability of the employee can be in the form of education and skills. Ability in the form of education has an important role in solving problems faced. With the increasing work ability of employees, it will improve employee performance. It is according to Sedarmayanti's statement (2010) that professional competence is a pillar that will place the bureaucracy as an effective control for the government and as a parameter of apparatus skills in achieving one's performance. Professional competence is one of the factors that affect employee performance. Employee professionalism is the potential of employees to carry out work that is charged to him effectively, efficiently and responsibly. For this reason, the work ability of employees has a considerable role in solving problems that occur.

The results of the research by Subari and Riady (2015) showed that individual competencies have a positive effect on employee performance. While the research of Ibrohim (2016) and Haryaka (2016) also shows the same thing that professional competence influences teacher performance. Based on the above theory and supported by previous research, the hypothesis can be formulated as follows:

$\mathrm{H}_{5}$ Professional competency has a positive effect on $\mathrm{HR}$ performance

\section{The Effect ofKnowledge SharingTowards Human Resources Performance}

Every organization has members, where each member works based on his knowledge, then managing his final knowledge is managing those members which means managing humans as well. Sharing knowledge with the organization will contribute to organizational performance especially in improving service quality (Matzler et al, 2008).

Sharing knowledge with organizations will contribute more the organizational performance, especially to improving service quality (Matzleret al, 2008). Knowledge sharing will improve the understanding of fellow members of the organization, so that among members will support each other who will eventually find the best work process for the organization in achieving maximum performance. Sharing knowledge will certainly improve understanding among fellow members, so that members will support each other.

Brink (2001) explains that the performance of an organization or company or anything can be successful if it can work together that is by having shared knowledge that is embedded in the minds of each member and manifested in practices involving all its members. Thus, the higher the role of someone in a variety of knowledge, then someone will have the ability to 
try to improve business performance. This is supported by the research of Hamzah and Djaya (2012) that knowledge sharing has a significant influence on company performance.

$\mathrm{H}_{6:} \quad$ Knowledge sharing has a positive effect on $\mathrm{HR}$ performance

\section{Empirical Model of Reasearch}

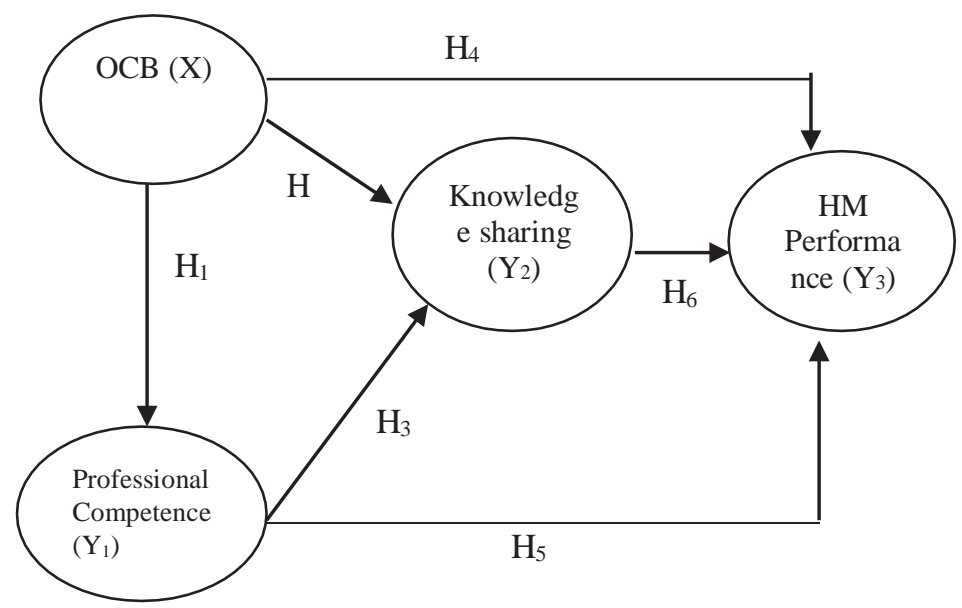

\section{RESEARCH METHOD}

\section{Population and Sample}

The population in this study was all employees of Regional Water Company (PDAM) Semarang, with a total sample 85 respondents. The sampling technique is ProportionalRandom Sampling. In order for data to represent each PDAM Semarang, such as PDAM Tirta Moedal, Semarang City, PDAM Tirto Panguripan, Kendal Regency and PDAM Ungaran, Semarang Regency, the distribution in this study was carried out using lottery methods.

\section{Data Analysis Method}

The method of data analysis uses quantitative analysis test with an analysis tool that is Partial Least Square. As for the regression equation:

$Y_{1}: \beta_{1} X+\varepsilon 1$

$Y_{2}: \beta_{2} X+\beta_{3} Y_{1}+\varepsilon 2$

$Y_{3}: \beta_{4} X+\beta_{5} Y_{1}+\beta_{6} Y_{2}+\varepsilon 2$

Information:

$\mathrm{Y}_{1}=$ professional Competence

$\mathrm{Y}_{2}=$ Knowledge sharing

$\mathrm{Y}_{3}=\mathrm{HM}$ Performance

$\mathrm{X}=O C B$

$\boldsymbol{\beta}=$ regresistandarizedcoeffesien

$\varepsilon \quad=$ Errorofterm

\section{The Direct and Indirect Effect}

The direct and indirect effects of knowing the intervening variables of professional competence and knowledge sharing are able to mediate between organizational acitizenship behavior towards HR performance. The criteria said to be able to mediate are: (Ghozali, 
2013) if the contribution of direct effect is smaller than the total indirect effect, then affective commitment is proven as an intervening variable

\section{RESULT}

\section{Partial Least Square}

Tabel 2

Line Model Equations

\begin{tabular}{|c|c|c|c|c|}
\hline & $\begin{array}{c}\text { original } \\
\text { sample } \\
\text { estimate }\end{array}$ & $\begin{array}{c}\text { mean of } \\
\text { subsamples }\end{array}$ & $\begin{array}{c}\text { Standard } \\
\text { deviation }\end{array}$ & $\begin{array}{c}\text { T- } \\
\text { Statistic }\end{array}$ \\
\hline $\mathbf{x}$-> Y1 & 0.904 & 0.897 & 0.021 & 43.858 \\
\hline $\mathbf{x}$-> Y2 & 0.429 & 0.410 & 0.106 & 4.050 \\
\hline Y1 -> Y2 & 0.538 & 0.558 & 0.105 & 5.102 \\
\hline $\mathbf{x}$-> Y3 & 0.166 & 0.182 & 0.081 & 2.047 \\
\hline Y1 -> Y3 & 0.173 & 0.209 & 0.116 & 2.060 \\
\hline Y2 -> Y3 & 0.693 & 0.692 & 0.127 & 5.435 \\
\hline
\end{tabular}

\section{HYPOTESIS TEST}

\section{Hypotesis Test 1 : The Effect of OCBon Professional Competence}

Based on the results of the output it can be seen that the T value of Statistics for variable organizational citizenship behavior towards professional competence obtained a value of 43.858 so that it had exceeded the provisions of 1.96. The explanation can be interpreted that the test is able to reject Ho and accept Ha, which means that OCB has a positive and significant effect on professional competence. Based on the test results it can be concluded that the $\mathbf{H}_{1}$ is accepted, so that the alleged positive effect between OCB on professional competence is proven or acceptable

\section{Hypotesis test2 : The Effect of Organizational Citizenship Behavior on Knowledge Sharing}

The results of the COB test on knowledge sharing obtained $\mathrm{T}$ statistic values of 4,050> 1,96. This explanation can be interpreted if Ho is rejected and Ha is accepted, which means that OCB testing has a positive and significant influence on knowledge sharing. Based on the results of the test it can be concluded that $\mathbf{H}_{2}$ is accpted, so that the alleged positive effect between OCB and knowledge sharing is proven or acceptable.

\section{Hypotesis test3: the Effet of Professional CompetenceonKnowledge Sharing}

The results of testing the professional competence of knowledge sharing obtained $\mathrm{T}$ Statistic value of 5.102> 1.96, meaning that Ho is rejected and Ha is accepted which means that professional competence has a positive and significant effect on knowledge sharing. Based on the results of the test it can be concluded that $\mathbf{H}_{3}$ is accepted, so that the presumption of a significant positive effect between professional competence on knowledge sharing is evident or acceptable 


\section{Hypotesis Test 4 : The Effect of OCBon HM Performance}

The test results between OCB on HR performance obtained the results of the T statistic of 2.047> 1.96. This can be interpreted if Ho is rejected and Ha is accepted which means that OCB on HR performance has a significant positive effect. Thus, it can be concluded that $\mathbf{H}_{\mathbf{4}}$ is accepted, so the allegations are proven.

\section{Hypothesis Test 5: The Effect of Professional Competence on HR Performance}

The results of the professional competence test on HR performance obtained T-Statistic values of 2.060> 1.96, which means that Ho is rejected and $\mathrm{Ha}$ is accepted. This explanation can be interpreted that professional competence has a significant positive effect on HR performance. Thus, it can be concluded that $\mathbf{H}_{5}$ is accepted, so that the allegations are proven or acceptable.

\section{Hypothesis Test 6: The Effect of Knowledge Sharing on HR Performance}

The results of testing the price of knowledges on HR performance obtained T-Statistic values of 5.435>1.96, which means that knowledge sharing has a significant positive effect on HR performance. Thus, it can be concluded that $\mathbf{H}_{6}$ is accepted, so that the alleged positive influence between knowledge sharing on HR performance is proven

\section{R Square}

Tabel 3

R Square

\begin{tabular}{|c|l|c|}
\hline No & \multicolumn{1}{|c|}{ Information } & $\begin{array}{c}\text { Adjusted } \\
\text { R Square }\end{array}$ \\
\hline 1. & Professional Cometence & 0,817 \\
2. & Knowledge sharing & 0,890 \\
3. & HM performance & 0,929 \\
\hline
\end{tabular}

The val ue of R Square for model 1 which is the indirect effect of organizational citizen ship behavior on professional competencies obtained a value of 0.817 , it can be interpreted that professional competence can be explained by OCB variables of $81.7 \%$, while the remainder is explained by other variables not examined in research. While the knowledge sharing is obtained by the value of $\mathrm{R}$ Square of 0.890 , meaning that knowledge sharing is able to be explained by both OCB variables and professional competence, which is equal to $89 \%$. While the direct influence between OCB, professional competence and knowledge sharing on HR performance obtained a value of 0.929 , which means that HR performance is able to be explained by the three OCB variables, professional competence and knowledge sharing of $92.9 \%$, 


\section{Direct and Indirect Effect}

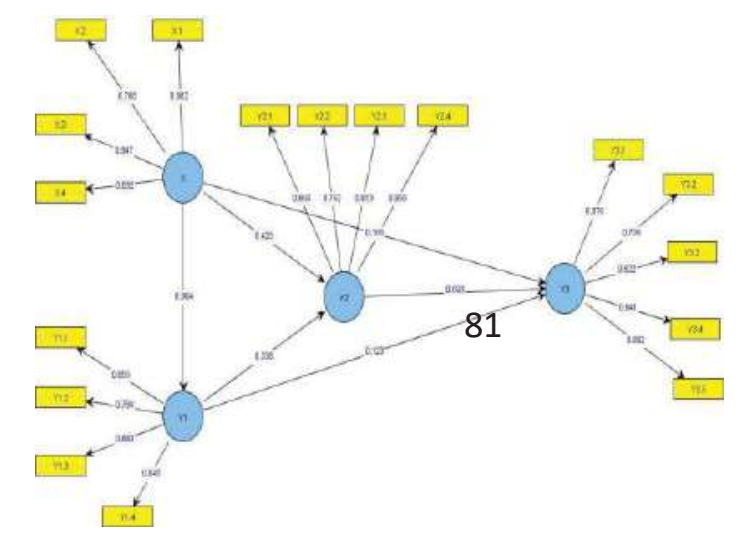

\section{The Effect of OCB on Knowledge Sharing through Professional Competence}

Based on the test results the analysis between organizational citzenship behavior towards professional competency through knowledge sharing, the regression coefficient value is 0.486 , while the direct effect between organizational citzenship behavior and knowledge sharing shows a value of 0.429 . Thus, the total indirect effect is $0.486>0.429$, giving an understanding that professional competence is capable of being an intervening variable between the organizational variables of citzenship behavior and knowledge sharing.

\section{The Effect of OCB on HR Performance through Professional Competence}

The test results of analysis between organizational citzenship behavior towards HR performance through professional competence obtained a regression coefficient value of 0.156 , while the direct influence between organizational citzenship behavior on HR performance was 0.166 , so indirect effects were $0.156<0.166$ which meant that professional competencies were not able to become variables intervening between organizational citzenship behavior towards HR performance.

\section{The Effect of Organizational Citzenship Behavior on HR Performance through Knowledge Sharing}

The test results between organizational citzenship behavior towards knowlede sharing leading to HR performance obtained a regression coefficient value of 0.297 , while the direct effect between organizational citzenship behavior on HR performance was 0.166 , so the indirect effect value was $0.297>0.166$. This explanation of providing knowledge sharing is able to become an intervening variable between organizational citzenship behavior towards HR performance.

\section{DISCUSSION}

\section{The Effect ofOrganizational Citzenship Behaviortowards Professional Competence}

The test results show that organizational citzenship behavior has a positive and significant effect on professional competence, meaning that the higher organizational citizenship behavior, the employee can control his own behavior to want to work extra so that it will make employees have competence because they are able to raise their professionalism as employees 
OCB behavior can be demonstrated if employees are more concerned with the interests of others, so as to be able to improve professional competence because employees have the ability to utilize information technology properly.

Based on this reason, it is important for employees to behave in a sporty manner, such as the habit of employees to be fair and honest in their work so that mastery of employee competency standards will increase. Especially if it is supported by employee behavior to have the desire to do work optimally it will make employees able to conduct studies as a form of responsibility to the company The attitude of respect that employees have shown by maintaining good relationships with fellow employees will certainly affect the level of difficulties faced by employees because employees can help each other.

According to Borman and Montowidlo (1993) in Novliadi (2007) that Organizational Citizenship Behavior can improve competence because employee behavior can be seen from social interactions in members of the organization to be smooth, reduce the occurrence of disputes, and increase efficiency. The results of this study support the findings of Triyanto (2008), who found that OCB has an effect on professional competence. By applying OCB, the professional competence of employees will increase. This is also supported by Lestari's research et al. (2015) if OCB has a positive influence on professional competence.

\section{The Effect of Organizational Citzenship Behavior on Knowledge Sharing}

Based on the results of research that organizational citzenship behavior has a positive and significant influence on knowledge sharing, it means that the higher the organizational citizenship behavior, the employee can control his own behavior to want to work extra so that it will encourage employees to share knowledge because there is an impulse that appears in OCB behavior can be shown if employees are more concerned with the interests of others, then it will make the employee will share knowledge through routine discussions.

For employees, sportsmanship behavior is very necessary, such as the habit of employees to be fair and honesty in work so that it will make employees want to exchange experiences. Especially if it is supported by the behavior of employees to have the desire to do the job optimally, it will create high employee participation in activities carried out by the company, such as workshops. The attitude of respect that employees have is shown by maintaining good relations with their friends will certainly affect the involvement of employees in sharing knowledge, namely through the involvement of seminars.

According to the statement Lovell (1999) OCB is a behavior that extends and exceeds what is required by the organization to share knowledge. This study supports the findings made by Hamzah and Djaya (2012) showing that increasing OCB affects knowledge sharing. The results of this study are consistent with the results of other studies such as Atak \& Ramazan (2010) and Ellinger et al (2013), which confirm that OCB has a positive influence on knowledge sharing.

\section{The Effect of Professional Competence on Knowledge Sharing}

The results showed that professional competence has a positive and significant competence on knowledge sharing, giving an understanding that the higher the professional 
competence possessed by employees, it will affect employees in carrying out work that give to him effectively, efficiently and responsibly so as to encourage employees to share knowledge due to there is an impulse that appears in him. It is important for management to improve the ability for employees to utilize information technology properly so that it will make employees share knowledge, namely through routine discussions.

Mastery of employee competency standards will certainly make employees have the desire to exchange experiences with other friend. It is important for employees to conduct assessments so that the involvement / participation of employees is needed if the work carried out has difficulties, through workshop activities. The ability of employees to overcome difficulties in the field related to complaints made by customers is very necessary so that it is important for employees to have an involvement to share knowledge through seminar activities.

Davenport \& Prusak (1998) that a person's professional competence arises because there is an incentive in him to share knowledge. The results of this study are also in line with the findings of Rodin, et al (2017) and Haryaka (2016) showing that professional competence influences knowledge sharing

\section{The Effect of Organizational Citzenship Behavior Toward HM Performance}

The results showed that organizational citzenship behavior has a positive and significant influence on HR performance, meaning that the higher organizational citizenship behavior, the employee can control his own behavior to have a strong willing to work extra to increase his potential, so that it will has an impact on achieving employee performance optimally. OCB behavior can be demonstrated if employees are more concerned with the interests of others, so as to improve the quality of work.

The sportsmanship of the employee will make the employee have the initiative to find the best step in the completion of the work. Moreover, if supported by employee behavior to have the desire to do the job optimally, it will make employees more accurate in their work. The attitude of respect that employees have is shown by maintaining good relationships with their Friends will certainly make employees have the ability to do cooperation.

According to Lovell (1999) argues that OCB is a behavior that extends and exceeds what behavior has been required by the organization to improve employee performance. The results of this study support the findings of Khazaei et. al. (2011); Suzana (2017); Rastgar, et.al. (2012); Harwiki (2013); Maharani, et.al. (2013), Putri and Utami (2017) show that organizational citizenship behavior has a positive effect on HR performance. Whereas Sudiro (2014) research, Ramadhani (2013) and Sanjaya and Setiawan (2017) show that organizational citizenship behavior does not affect employee performance.

\section{The Effect of Professional Competence towards HM Performance}

The results show that professional competence has a positive and significant effect on HR performance, it means that the higher the professional competence possessed by employees, it will affect employees in carrying out the work give to him effectively, efficiently and responsibly so that the employee's performance will be maximized. The ability for employees 
to make good use of information technology will certainly affect the improvement in the quality of work produced by employees.

Mastery of employee competency standards will certainly make employees have the initiative to find the best steps in improving the performance produced. It is important for employees to conduct a duty if the work carried out encounters difficulties so it will increase accuracy for employees to complete the work. The ability of employees to overcome difficulties in the field related to complaints made by customers is very necessary in an effort to improve cooperation capabilities.

According to Sedarmayanti (2010), professional competence is a pillar that will place the bureaucracy as an effective machine for the government and as a parameter of apparatus skills in achieving one's performance. Professional competence is one of the factors that affect employee performance. The results of the research by Subari and Riady (2015) showed that individual competencies have a positive effect on employee performance. While the research of Ibrohim (2016) and Haryaka (2016) also shows the same thing that professional competence influences teacher performance.

\section{The Effect of Knowlede Sharing Towards HM Performance}

The results show that knowledge sharing had a significant positive effect on HR performance, means that the higher the employee has a broad opportunity to express opinions, ideas, criticisms, and comments to other members, the more employee's performance will be maximized. By conducting regular discussions with fellow co-workers or work teams of course the problems can be solved easily, so that it will improve the quality of work produced.

Employee performance may need to exchange experiences so it will make employees have the initiative to find the best steps. Because of this reason, it is important for employees to have a high involvement in activities carried out by companies such as workshops so that they will be able to increase high accuracy for employees to complete work. Knowledge sharing activities through seminars will certainly have a high impact on the ability of employees because they can improve cooperation.

Sharing knowledge with organizations will contribute more to organizational performance, especially to improving service quality (Matzler et al, 2008). Brink (2001) explains that the performance of an organization or company or anything can be successful if it can work together that is by having shared knowledge that is embedded in the minds of each member and manifested in practices involving all its members. Thus the higher the role of someone in a variety of knowledge, then someone will have the ability to try to improve business performance. The results of this study support the findings of Hamzah and Djaya (2012) that knowledge sharing has a significant influence on company performance.

\section{Direct and Indrect Effect}

Professional competence is able to become an intervening variable between organizational citizenship behavior to knowledge sharing, giving understanding that the more employees can control their own behavior to work extra, so that employees have competence 
because they are able to raise their professionalism as employees of their abilities so that they will increase professional competence employee.

Professional competence is not able to be an intervening variable between organizational citizenship behaviors towards HR performance. Thus, organizational citizenship behavior can only influence HR performance not necessarily through professional competence. Thus, high organizational citizenship behavior is only able to make employees able to control their own behavior to want to work extra in maximizing employee performance, not necessarily through professional competence.

Knowledge sharing is able to become an intervening variable between organizational citizenship behavior towards HR performance, giving an understanding that the more employees can control their own behavior to want to work extra, then to encourage employees to share knowledge because there is an impulse that arises so that they can maximize employee performance.

Knowledge sharing is able to become an intervening variable between professional competency and HR performance, giving the understanding that the more employees are able to carry out work that is charged to him effectively, efficiently and responsibly then encourage employees to share knowledge because there is an impulse that arises in him so that it will impact performance employees maximally.

\section{CONCLUSION}

\section{Conclusion}

Based on the research that has been done, the following conclusions can be obtained:

1. OCB has a positive effect on professional competence, it means that the higher the organizational citizenship behavior, the employee can control his own behavior to want to work extra so that it will make employees have competence because they are able to raise their professionalism as employees of their abilitiesOCB

2. OCB has a positive effect on knowledge sharing; it means that the higher OCB, the employee can control his own behavior to want to work extra so that it will encourage employees to share knowledge because there is an impulse that arises in him.

3. Professional competence has a positive influence on knowledge sharing, giving an understanding that the higher the professional competence possessed by employees, it will affect employees in carrying out work that give to him effectively, efficiently and responsibly so as to encourage employees to share knowledge because there is an impulse that arises in him.

4. OCB has a positive effecct on HR performance, meaning that the higher $\mathrm{OCB}$, the employee can control his own behavior to want to work extra to increase his potential, so that it will has an impact on achieving maximum employee performance

5. Professional competence has a positive effect on HR performance, means understanding that the higher the professional competence possessed by employees, it will affect employees in carrying out the work assigned to him effectively, efficiently and responsibly so as to improve employee performance to the maximum. 
6. Knowledge sharing has a positive effect on the performance of HR giving the understanding that the higher the employee has a broad opportunity to express opinions, ideas, criticisms, and comments to other members, the more the employee's performance will be maximized.

For the further research, it is necessary to expand the research object, such as all employees in the PDAM in Central Java so it can reflect the accuracy of the research data and generalize the working conditions at a wider place or organization

\section{REFERENCES}

Andrawina, Luciana, dkk 2008, Hubungan antara knowledge sharing capability, absorptive capacity dan mekanisme formal: Studi kasus industri teknologi informasi dan komunikasi di Indonesia. Jurnal teknik industri Vol. 10 No. 2 Hal. 158-170

Arikunto, Suharsimi, 2012, Prosedur Penelitian Suatu Pendekatan Praktek, Bina Aksara, Jakarta

Armanu Fatchur Rohman dan Mandayanti, 2011, Pengaruh pemberdayaan psikologi dan komitmen afektif terhadap kepuasan kerja dan kinerja pegawai, Jurnal Aplikasi manajemen Vol. 1 No. 1.ISSN :1693-5341

Buchel, Felix and Matthias Pollmann-Schult, 2014, Overeducation and human capital endowments, The emerald research register for this journal is available

Christa, Usup Riassy, 2013, Peran human capital dan structural capital dalam meningkatkan kinerja organisasi (suatu kajian konseptual), Jurnal Sains Manajemen, Vol. 1 No.1 ISSN : 2302-1411

Dessler, Gary. 2012.Manajeman Sumber Daya Manusia, Prenhallindo, Jakarta

Ferdinand, Augusty. 2009, Metode Penelitian Manajemen. Semarang, BP.UNDIP

Fitriyana, 2012, Knowledge Acquisition pada Knowledge Based Economy ERA, System Teknologi Informasi. Universitas Gajah Mada. Yogyakarta

Ghozali, Imam. 2013. Aplikasi Analisis Multivariate Dengan Program SPSS. Badan Penerbit Universitas Diponegoro. Semarang.

Haryaka, 2016. Pengaruh kompetensi professional dan komitmen organizational terhadap kinerja guru di moderasi Budaya organizational. Jurnal. Manajemen Bisnis Vol. 3 No. 2 Hasibuan, Malayu SP., 2012, Manajemen Sumber Daya Manusiạ, STIE YKPN, Yogyakarta

Hakim, Adnan, 2015, Contribution of competence teacher (pedagogical, personality, professional competence and social) on the performance of learning. The International Journal of Engineering and Science (IJES) Volume 4 No. 2 PP : 01-12. ISSN :23191813

Husammi, Endo W.2008, Pengaruh komitmen afektif dan human capital terhadap kinerja SDM dengan knowledge sharing sebagai variabel intervening. Jurnal Ekobis, Vol. 2 No. 1 
Ibrohim. 2016. Pengaruh kompetensi professional dan motivasi kerja terhadap kinerja guru dimoderasi kepemimpinan kepala sekolah. Jurnal. Manajemen Bisnis Vol. 3 No. 2

Mangkunegara, A.A. Anwar Prabu, 2012, Manajemen Sumber Daya Manusia, Rineka Cipta, Jakarta

Putri, Yumma Dalian dan Hamidah Nayati Utami. 2017. Pengaruh organizational citizenship behavior terhadap kinerja. Jurnal Administrasi Bisnis (JAB) Vol. 46 No. 1 Hal 27-34

Ramanda, Yuli dan Bustari Muchtar, 2016, Pengaruh human capital, relational capital dan organizational behavior terhadap kinerja pegawai, Jurnal Ekonomi Bisnis. Vol. 3 No.2

Robbins, Stephen P., 2012, Perilaku Organisasi : Konsep - Kontroversi - Aplikasi, Jilid 2, PT. Prehallindo, Jakarta

Rachmawati, D., dan F. Wulani. 2014. "Human Capital dan Kinerja Dareah: Studi Kasus di Jawa Timur", Penelitian APTIK, April: 1-73 FE-Universitas Indonesia, Agustus: 1-21

Riduwan, 2005, Skala Pengukuran Variabel-Variabel Penelitian, Alfabeta, Bandung

Shannak., Bao, Gongmin, 2009, An Empirical Study on Knowledge Sharing, Affectif Commitment,Perceived Task Interdependence and Job Involvment in Chinese Accounting Firms, PICMET, IEEE, Istanbu

Setiarso, Bambang 2013. Knowledge Sharing in Organizations: models and mechanism”. Kualalumpur (Malaysia) : Special Library Conference

Siagian, Sondang. P. 2009. Administrasi Pembangunan, Gunung Agung, Jakarta

Simamora, Henry, 2012, Manajemen Sumber Daya Manusia, STIE YKPN, Yogyakarta

Subari, Subari and Hanes Riady, 2015, Influence of training, competence and motivation on employee performance, moderated by internal communication. American Journal of Business and Management. Vol. 4 No. 3 PP : 133-145

Sugiyono, 2012, Metodologi Penelitian, Alfa Beta, Jakarta

Suzana, Anna. 2017. Pengaruh organizational citizenship behavior tehradap kinerja karyawan. Jurnal Logika Vol. XIX. p-IISN :1978-2560 E-ISSN : 2442-5176. Hal $42-50$

Umar, Husein, 2012, Metodologi Penelitian : Aplikasi dalam Pemasaran, PT. Gramedia Pustaka Utama, Jakarta

Widjajanti, Kesi dan Widodo, 2014, Pengembangan inovasi organisasi berbasis human capital, sharing knowledge sharing dan pembebelajaran organisasi. Ekobis Vol 15 No 1 Hal 86101

Widodo, 2009, Model pengembangan human capital dalam konteks modal social, Benefit Jurnal Manajemen dan Bisnis Volume 13 No. 2 Hal. 88-106

Wulani, F. 2005. Sikap Kerja dan Implikasinya dalam Pengelolaan Sumber Daya Manusia : Suatu Kajian terhadap Organizational Citizenship Behavior. Jurnal Studi Bisnis. Vol. 3, No.1, Hal. 13-25 
Yuwono, Susatyo, dkk, 2014, Hubungan antar motivasi kerja dan kepuasan kerja dengan organizational citizenship behavior, Seminar Nasional dan Call for Paper, ISBN : 978602-70429-1-9 Hal. 444-451

Zaied, A.N.H. 2012. An Integrated Knowledge Management Capabilities Framework for Assessing Organizational Performance. International Journal 